Check for updates

London

Cite this as: BMJ 2021;373:n1658 http://dx.doi.org/10.1136/bmi.n1658 Published: 29 June 2021

\section{Covid-19: Events pilot finds "no substantial outbreaks," but experts point to gaps in evidence}

\author{
Ingrid Torjesen
}

Just 28 positive cases of SARS-CoV-2 infection were identified among more than 58 ooo people who attended nine large events in April and May included in a pilot programme set up to examine the risks of transmission and how they can be reduced.

But although the evaluation of the first phase of the government's Events Research Programme found "no substantial outbreaks," ${ }^{1}$ it conceded that it was a challenge "to generate robust, generalisable evidence of the transmission risk associated with particular events" because of the low prevalence of the virus at the time and the low uptake of PCR testing before and after the events.

The report said that although there was a risk of virus transmission at indoor and outdoor events the risk was greater at indoor events with a high crowd density and at "pinch points" in all venues where people may congregate for long periods, such as the entrance and exit, toilets, and refreshment areas. Mitigation strategies such as face coverings, ventilation, testing, restrictions on food and drink, and social distancing and capacity caps all contributed to reducing the risk of virus transmission, it said.

All those attending the events had to provide a negative lateral flow test result as a condition of entry and were also asked to take a voluntary PCR test before and after the event to aid the programme's research. But only $24 \%$ of participants took a PCR test before and only $28 \%$ took one after, with $15 \%$ overall taking both.

Compliance with social distancing, face covering, and testing requirements was generally high across all events where they were required, but contact tracing found evidence of people with covid symptoms having attended events and one case of an individual seeking multiple lateral flow tests after a positive result to acquire a negative result.

Paul Hunter, professor in medicine at the University of East Anglia, said, "The fact that symptomatic individuals were still trying to gain access to these venues even when they were told not to and that they knew they would be screened is worrying."

The indoor events in the evaluation included the Circus nightclub in Liverpool, which hosted nearly 7000 people over two nights and saw 10 cases recorded, the World Snooker Championship in Sheffield, which saw six cases recorded among more than 10 ooo attendees over 17 days, and the BRIT Awards in London, which saw no cases recorded among 3500 people. Fewer cases were recorded at the pilot outdoor events, which included the FA Cup semi-final at Wembley, an outdoor festival at Sefton
Park in Liverpool, and the Reunion 5k run at Kempton Park racecourse.

Of the 28 cases identified after the events, 11 were index cases considered to have been infected before an event and potentially infectious at the event, and 17 were secondary cases considered to have been infected at or after the time of the event.

Lateral flow tests identified 10 cases of SARS-CoV-2 infection in people who had been due to attend an event.

Jon Deeks, professor of biostatistics and head of the Biostatistics, Evidence Synthesis and Test Evaluation Research Group at the University of Birmingham, said the 11 index cases identified by PCR testing had been identified in people who had returned false negative lateral flow test results. "If the same rate of false negatives occurred in the three quarters not returning a PCR test, then the lateral flow test would have identified 10 out of 54 cases: less than one in five. While detecting some cases is better than none, allowing such a high proportion of people who are infected into events is not safe," he said.

Lawrence Young, a virologist and professor of molecular oncology at Warwick Medical School, said that though the reported infection levels were low the results were "compromised" by the low uptake of PCR testing. "Coupled with the inaccuracy of lateral flow tests, these results provide little confidence that the larger events associated with the third phase of the ERP [Events Research Programme] will provide any meaningful data."

The second phase of events in the pilot has already taken place, including the group stage UEFA Euro 2020 matches hosted at Wembley Stadium, the Download Pilot music festival, the England versus New Zealand cricket test match at Edgbaston, and horse races at Royal Ascot. Data from these events are still being gathered and analysed.

The third phase has yet to be finalised but will include Wimbledon tennis championships, the Goodwood Festival of Speed motor racing event, and the Latitude music festival.

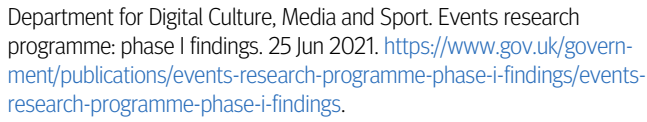

This article is made freely available for use in accordance with BMJ's website terms and conditions for the duration of the covid-19 pandemic or until otherwise determined by BMJ. You may use, download and print the article for any lawful, non-commercial purpose (including text and data mining) provided that all copyright notices and trade marks are retained. 